\title{
A review of corneal diameter, curvature and thickness values and influencing factors*
}

\author{
KP Mashige
}

Discipline of Optometry, School of Health Sciences, University of KwaZulu-Natal, Private Bag X54001, Durban, 4000 South Africa

<mashigek@ukzn.ac.za>

Received 1 October 2013; revised version accepted 3 December 2013

\begin{abstract}
The cornea is an important ocular structure involved in the mediation of visual perception. It is the principal refractive surface of the eye and vision can be significantly affected by relatively small changes in its structure and parameters. Measurement of corneal parameters is important in the diagnosis and management of ocular diseases such as keratoconus and glaucoma, and also in the fitting of contact lenses or with refractive surgery such as Laser-Assisted in situ Keratomileusis
\end{abstract}

(LASIK) and photorefractive keratectomy (PRK). The human corneal diameter, anterior curvature and centre thickness as well as factors influencing them are reviewed in this article. This review will be useful to eye care professionals who routinely measure these parameters when fitting contact lenses and assessing, diagnosing as well as managing corneal and other ocular conditions. (S Afr Optom 2013 72(4) 185-194)

Key words: Corneal parameters, corneal diameter, anterior corneal curvature, central corneal thickness

\section{Introduction}

Until recently, the cornea has been known to be composed of five layers; which from the anterior to posterior are the epithelium, Bowman's layer, stroma, Descemet's membrane and the endothelium ${ }^{1}$. A sixth layer called the Dua's layer, composed predominantly of type-1 collagen bundles, has recently been discovered and is located between the stroma and Descemet's membrane ${ }^{2}$. Including the tear film, the cornea is the first structure that light passes through, and these layers behave as converging lenses that direct incident light rays towards the pupil ${ }^{1}$. The cornea is the most significant refractive structure of the eye, contributing approximately two-thirds of the eye's refractive power ${ }^{1}$. Corneal refractive power is attributable ${ }^{1}$ to its shape and the relatively large difference between its refractive index (1.376) and that of air (1).
Measurements of corneal parameters in their entirety are important for both diagnostic and therapeutic purposes. Many ocular pathological conditions such as keratoconus, glaucoma and ocular manifestations of diabetes mellitus cause changes in corneal architecture, leading to poor visual outcomes ${ }^{3}$. Abnormally small or large corneal diameters are used to diagnose microcornea and megalocornea respectively. Microcornea refers to a small corneal diameter, and may be unilateral or bilateral and is usually associated with other ocular abnormalities such as optic nerve hypoplasia, scleroderma, cataract formation, iris abnormalities and secondary angleclosure glaucoma ${ }^{4}$. In megalocornea, the cornea is abnormally large, and is usually associated with myopia, astigmatism, cataracts and, later on in life, lens dislocation and glaucoma ${ }^{4}$. Smaller diameters are found in Fuchs and macular corneal dystrophies, whereas diameters are larger in keratoconus and lattice 
and granular dystrophies 5 . A cornea that is too curved (radii are abnormally small) is found in keratoconus and a cornea that is too flat is found in conditions such as cornea plana, which is a rare bilateral condition associated with severe refractive errors, cataracts and coloboma ${ }^{6}$. Also, a thin cornea leads to underestimation of the intraocular pressure (IOP) whereas a thick cornea results in overestimation ${ }^{3}$. Due to the relationship between central corneal thickness (CCT) and IOP, low CCT values may lead to a delay in the diagnosis and treatment of glaucoma ${ }^{3}$ which may in turn lead to visual impairment and blindness.

Considering the improvement in the technology for measuring ocular parameters and the surge in interest in corneal measurement in recent years, the author wishes to review the ocular parameters as presented here. Therefore the aim of this paper is to review three corneal parameters that are commonly measured by eye care practitioners, namely diameter, anterior curvature and centre thickness. Included also are the clinical importance of each parameter, methods of measurement, biometric values and factors influencing the values.

\section{Corneal parameters}

\section{Corneal diameter}

The corneal diameter (CD) is the limbus-to-limbus distance and clinically both the horizontal and vertical dimensions are regarded as important. The horizontal corneal diameter (horizontal visible iris diameter, HVID) is the distance between the nasal and temporal imaginary limbal tangents to the corneal circumference, HVID includes the centre of the pupil, as does the vertical visible iris diameter, $\mathrm{VVID}^{7}$. The corneal diameter is clinically important for many reasons. For example, it is important in ensuring that a soft lens total diameter is sufficient to maintain full corneal coverage ${ }^{8}$. Also, the accurate measurements of $\mathrm{CD}$ might be a useful approximation for sizing and producing anterior chamber intraocular lenses ${ }^{9}, 10$. Further, CD measurement is important in the accurate diagnosis of diseases such as microcornea, megalocornea, relative microphthalmos, and corneal dystrophies ${ }^{11}$.

Routinely, in optometric practice, CD is often measured with a hand-held millimeter ruler, a ruler combined with a magnifier or use of the slit-lamp graticule ${ }^{11}$. But CD can be more accurately measured with the instruments such as an autorefractometer (for example, the Canon Autoref R-1), corneal topographers such as the Orbscan II system and via optical coherence tomograph ${ }^{12}$.

The horizontal diameter of the cornea on average is $10 \mathrm{~mm}$ in infants and $11 \mathrm{~mm}$ in adults while the vertical diameter is usually $11 \mathrm{~mm}$ in infants and $12 \mathrm{~mm}$ in adults ${ }^{11,13}$. From the literature, normative values for corneal diameters are shown in Table 1.

\section{Anterior corneal curvature}

The anterior corneal curvature (ACC) relates to the shape of the front surface of the cornea and is one of the important measurements used to characterize optical properties of the cornea ${ }^{4}$. In clinical practice, both horizontal and vertical anterior corneal curvatures are usually measured. The average cornea has a smaller radius in the vertical meridian compared to the horizontal meridian, which contributes to higher incidence of with-the-rule astigmatism in young adults ${ }^{1}$. Anterior curvature expressed in radii (typically millimeters) is important for contact lens fitting and management ${ }^{8}$, ocular aberration analysis, corneal refractive surgery as well as diagnoses and management of corneal pathological conditions such as keratoconus ${ }^{22}$.

Measurement of ACC can be made with a variety of instruments, such as a keratometer, IOLMaster, or corneal topographer ${ }^{5,6}$. Although the keratometer provides a reliable and accurate assessment of the ACC, the instrument measures the corneal curvature based on an approximate central area of $3.2 \mathrm{~mm}$ of its surface. Also, the calculation of corneal radius assumes the cornea to be a sphere with a refractive index of 1.3375 , which is not true ${ }^{1,4}$. According to Veys et $a l^{8}$, the variations in curvature across the surface of the cornea can be quantified by calculating the shape factor at different points across its surface. The shape factor can be described in terms of eccentricity $(e)$, where shape factor $(p)=1-e^{2}$. The shape factor varies between 0 and 1 , where 1 is a perfect sphere. Techniques such as keratoscopy provide a measurement of shape factor, so the change in contour across the whole cornea can be assessed more comprehensively ${ }^{8}$. Table 2 below shows the range of ACC in normal populations. 
Table 1: The range of normal CD in the human population as found in the literature. HVID = horizontal visible iris diameter, VVID = vertical visible iris diameter, $\mathrm{M}=$ male, $\mathrm{F}=$ female, $\mathrm{ID}=$ indirect caliper, $\mathrm{OCT}=$ ocular coherence tomography, $\mathrm{CT}=\mathrm{corneal}$ topography, SSCT = scanning-slit corneal topography and $\mathrm{NR}=$ not reported.

\begin{tabular}{|c|c|c|c|c|c|c|c|c|c|}
\hline Author/s & $\begin{array}{l}\text { Race/ } \\
\text { Ethnicity }\end{array}$ & Method & No of Eyes & Age (years) & Gender & $\begin{array}{l}\text { HVID }(\mathrm{mm}) \\
\text { Range }\end{array}$ & Mean \pm SD & $\begin{array}{l}\text { VVID }(\mathrm{mm}) \\
\text { Range }\end{array}$ & $\operatorname{Mean} \pm$ SD \\
\hline $\begin{array}{l}\text { Ganguli et } a l^{14} \\
\text { (1975) }\end{array}$ & Indians & PD ruler & 100 & $5-53$ & $\begin{array}{l}\mathrm{M} \\
\mathrm{F}\end{array}$ & NR & $\begin{array}{l}11.45 \\
11.20\end{array}$ & NR & $\begin{array}{l}10.86 \\
10.67\end{array}$ \\
\hline $\begin{array}{l}\text { Baumeister } \text { et } a l^{15} \\
\text { (2004) }\end{array}$ & Caucasians & $\begin{array}{l}\text { Caliper } \\
\text { IOLMaster } \\
\text { Orbscan } \\
\text { Holladay-Godwin } \\
\text { gauge }\end{array}$ & $\begin{array}{l}100 \\
100 \\
100 \\
100 \\
100\end{array}$ & NR & NR & NR & $\begin{array}{l}11.91 \pm 0.71 \\
12.02 \pm 0.38 \\
11.78 \pm 0.43 \\
11.8 \pm 0.60\end{array}$ & NR & NR \\
\hline $\begin{array}{l}\text { Rufer et } a l^{11} \\
(2005)\end{array}$ & Caucasians & Orbscan & 743 & $10-80$ & $\mathrm{M} \& \mathrm{~F}$ & $10.7-12.58$ & $11.71 \pm 0.42$ & NR & NR \\
\hline $\begin{array}{l}\text { Ashaye } e t a l^{9} \\
(2006)\end{array}$ & $\begin{array}{l}\text { Africans } \\
\text { (Nigerians) }\end{array}$ & ID & 684 & $0-0.65$ & $\mathrm{M} \& \mathrm{~F}$ & $9-12.5$ & $10.26 \pm 0.59$ & NR & NR \\
\hline $\begin{array}{l}\text { Kohnen et } a l^{16} \\
(2006)\end{array}$ & Caucasians & $\begin{array}{l}\text { IOLMaster } \\
\text { Orbscan }\end{array}$ & 52 & NR & $M \& F$ & NR & $\begin{array}{l}12.17 \pm 0.45 \\
11.84 \pm 0.41\end{array}$ & NR & NR \\
\hline $\begin{array}{l}\text { Pinero et } a l^{12} \\
(2008)\end{array}$ & Caucasians & $\begin{array}{l}\text { OCT } \\
\mathrm{CT}\end{array}$ & $\begin{array}{l}30 \\
30\end{array}$ & $20-51$ & $M \& F$ & $\begin{array}{l}10.03-12.92 \\
11.34-13.16\end{array}$ & $\begin{array}{l}11.76 \pm 0.52 \\
12.25 \pm 0.49\end{array}$ & NR & NR \\
\hline $\begin{array}{l}\text { Salouti et } a l^{17} \\
(2009)\end{array}$ & Iranians & $\begin{array}{l}\text { Galilei } \\
\text { EyeSys } \\
\text { Orbscan }\end{array}$ & $\begin{array}{l}74 \\
74 \\
74\end{array}$ & $27.4 \pm 7.2$ & $\mathrm{M} \& \mathrm{~F}$ & $\begin{array}{l}10.37-13.72 \\
10.7-14.59 \\
11.1-12.5\end{array}$ & $\begin{array}{l}12.01 \pm 0.61 \\
12.09 \pm 0.87 \\
11.67 \pm 0.29\end{array}$ & NR & NR \\
\hline $\begin{array}{l}\text { Venkataraman et al }{ }^{18} \\
(2010)\end{array}$ & Indians & $\begin{array}{l}\text { Orbscan } \\
\text { Eyemetrics }\end{array}$ & $\begin{array}{l}73 \\
73\end{array}$ & NR & $M \& F$ & NR & $\begin{array}{l}11.74 \pm 0.32 \\
11.92 \pm 0.33\end{array}$ & NR & NR \\
\hline $\begin{array}{l}\text { Hashemi et } a l^{13} \\
\text { (2010) }\end{array}$ & Iranians & Orbscan & 800 & $14 \&>$ & $M \& F$ & $10.76-12.6$ & 11.68 & NR & NR \\
\hline $\begin{array}{l}\text { Dinc et } a l^{19} \\
(2010)\end{array}$ & Turks & $\begin{array}{l}\text { IOLMaster } \\
\text { Orbscan }\end{array}$ & $\begin{array}{l}80 \\
80\end{array}$ & NR & $\mathrm{M} \& \mathrm{~F}$ & NR & $\begin{array}{l}11.87 \pm 0.35 \\
11.65 \pm 0.32\end{array}$ & NR & NR \\
\hline $\begin{array}{l}\text { Iyamu \& Osuobeni }{ }^{7} \\
(2012)\end{array}$ & $\begin{array}{l}\text { Africans } \\
\text { (Nigerians) }\end{array}$ & Ruler & 130 & $20-79$ & $\mathrm{M} \& \mathrm{~F}$ & $10-12$ & $11.39 \pm 0.69$ & $10-11$ & $10.5 \pm 0.5$ \\
\hline $\begin{array}{l}\text { Sanchis-Gimeno et } a l^{20} \\
\text { (2012) }\end{array}$ & Caucasians & SSCT & $\begin{array}{l}198 \\
181 \\
379\end{array}$ & $18-53$ & $\begin{array}{l}M \\
F \\
M \& F\end{array}$ & $\begin{array}{l}11.6-12.2 \\
11.5-12.3 \\
11.5-12.3\end{array}$ & $\begin{array}{l}11.9 \pm 0.2 \\
11.8 \pm 0.2 \\
11.9 \pm 0.2\end{array}$ & NR & NR \\
\hline $\begin{array}{l}\text { Zha et } a l^{21} \\
(2013)\end{array}$ & Chinese & Orbscan & 129 & NR & $M \& F$ & $10.5-12.4$ & $10.57 \pm 0.34$ & NR & NR \\
\hline
\end{tabular}


Table 2: The studies of ACC of the normal human population are indicated. HK $=$ horizontal corneal curvature, VK $=$ vertical corneal curvature, $\mathrm{AVK}=$ average corneal curvature, $\mathrm{M}=$ male, $\mathrm{F}=$ female, $\mathrm{KT}=$ keratometer, $\mathrm{PEK}=$ photo electronic keratoscope, TMS-1 = topographic modeling system and NR = not reported.

\begin{tabular}{|c|c|c|c|c|c|c|c|c|c|c|}
\hline Author/s & $\begin{array}{l}\text { Race/ } \\
\text { ethnicity }\end{array}$ & Method & $\begin{array}{l}\text { No of } \\
\text { Eyes }\end{array}$ & $\begin{array}{l}\text { Age } \\
\text { (years) }\end{array}$ & Gender & $\begin{array}{l}\text { HK }(\mathbf{m m}) \\
\text { Range }\end{array}$ & $\operatorname{Mean} \pm$ SD & $\begin{array}{l}\text { VK }(\mathbf{m m}) \\
\text { Range }\end{array}$ & $\operatorname{Mean} \pm$ SD & AVK \\
\hline $\begin{array}{l}\text { Ganguli et } a l^{14} \\
\text { (1975) }\end{array}$ & Indians & KT & 100 & $5-53$ & $\begin{array}{l}\mathrm{M} \\
\mathrm{F}\end{array}$ & NR & NR & NR & NR & $\begin{array}{l}7.75 \\
7.65\end{array}$ \\
\hline $\begin{array}{l}\text { Kiely et } a l^{23} \\
(1984)\end{array}$ & Caucasians & PEK & 196 & $21-40$ & M & $7.10-8.75$ & $7.79 \pm 0.26$ & $7.06-8.66$ & $7.69 \pm 0.28$ & NR \\
\hline $\begin{array}{l}\text { Fledelius \& } \\
\text { Stubgaard }^{24} \\
(1986)\end{array}$ & Caucasians & KT & 454 & $5-80$ & $\begin{array}{l}\mathrm{M} \\
\mathrm{F}\end{array}$ & NR & NR & NR & NR & $\begin{array}{l}7.93 \\
7.75\end{array}$ \\
\hline $\begin{array}{l}\text { Guillon et } a l^{25} \\
\text { (1986) }\end{array}$ & Caucasians & PEK & 220 & NR & $\mathrm{M} \& \mathrm{~F}$ & $7.14-8.54$ & $7.87 \pm 0.25$ & $7.03-8.46$ & $7.7 \pm 0.27$ & NR \\
\hline $\begin{array}{l}\text { Dunne } e t a l^{26} \\
\text { (1991) }\end{array}$ & Caucasians & KT & 60 & $19-25$ & $\mathrm{M} \& \mathrm{~F}$ & NR & $7.92 \pm 0.03$ & NR & $7.81 \pm 0.03$ & NR \\
\hline $\begin{array}{l}\text { Lam \& } \operatorname{Loran}^{27} \\
\text { (1991) }\end{array}$ & $\begin{array}{l}\text { Caucasians } \\
\text { Chinese }\end{array}$ & $\begin{array}{l}\text { PEK } \\
\text { PEK }\end{array}$ & $\begin{array}{l}63 \\
64\end{array}$ & $\begin{array}{l}18-28 \\
18-28\end{array}$ & $\begin{array}{l}\mathrm{M} \\
\mathrm{M}\end{array}$ & $\begin{array}{l}7.10-8.36 \\
7.21-8.31\end{array}$ & $\begin{array}{l}7.98 \pm 0.21 \\
7.47 \pm 0.24\end{array}$ & $\begin{array}{l}7.29-8.43 \\
7.46-8.48\end{array}$ & $\begin{array}{l}8.03 \pm 0.20 \\
7.9 \pm 0.23\end{array}$ & NR \\
\hline $\begin{array}{l}\text { Lam \& } \\
\text { Douthwaite } 28 \\
(1996)\end{array}$ & Chinese & KT & 24 & $19-25$ & $\mathrm{M} \& \mathrm{~F}$ & NR & $7.87 \pm 0.26$ & NR & $7.66 \pm 0.29$ & NR \\
\hline $\begin{array}{l}\text { Cheung et } a l^{29} \\
(2000)\end{array}$ & Chinese & TMS-1 & 63 & $18-37$ & $\mathrm{M} \& \mathrm{~F}$ & NR & $7.82 \pm 0.26$ & NR & $7.64 \pm 0.26$ & NR \\
\hline $\begin{array}{l}\text { Iyamu \& Eze }{ }^{30} \\
(2011)\end{array}$ & $\begin{array}{l}\text { Africans } \\
\text { (Nigerians) }\end{array}$ & KT & 95 & $20-69$ & $\mathrm{M} \& \mathrm{~F}$ & $7.42-8.38$ & $7.87 \pm 0.4$ & $7.34-8.48$ & $7.81 \pm 0.36$ & $7.85 \pm 0.35$ \\
\hline
\end{tabular}

\section{Central corneal thickness}

Central corneal thickness (CCT) and its measurement are important in many eye care procedures, such as tonometry and refractive surgery ${ }^{31}$. Several studies ${ }^{32-34}$ have shown that CCT significantly influences the measured IOP and consequently, the classification and management of glaucoma. Thinner than average corneas may result in underestimation of the true IOP, while thicker than average corneas may result in overestimation of $\mathrm{IOP}^{3}$. However, this factor alone is insufficient when explaining the increased susceptibility to glaucoma found in those with thinner corneas $^{3}$. The detection and management of contact lens related complications and certain surgical procedures (such as astigmatic keratectomy, LASIK, PRK and Intacs placement) rely on the accurate measurement of $\mathrm{CCT}^{35}$.

Corneal pachymetry is the process of measuring the thickness of the cornea and can be done using contact methods such as ultrasound and confocal microscopy or non-contact methods such as optical biometry with a single Scheimpflug camera (such as the Oculus Pentacam or Sirius), Dual Scheimpflug (for example, Galilei), coherence tomography (Visante, iVue or others), optical coherence pachymetry (with Orbscan) $)^{35}$. Average normal values for the human CCT as measured with different methods of pachymetry are shown in Table 3. 
Table 3: Summary of CCT studies conducted on different ethnic groups. UP $=$ ultrasonic pachymetry, UPS $=$ ultrasound pachymetry, $\mathrm{TP}=$ tono-pachymeter, $\mathrm{M}=$ male, $\mathrm{F}=$ female and $\mathrm{NR}=$ not reported.

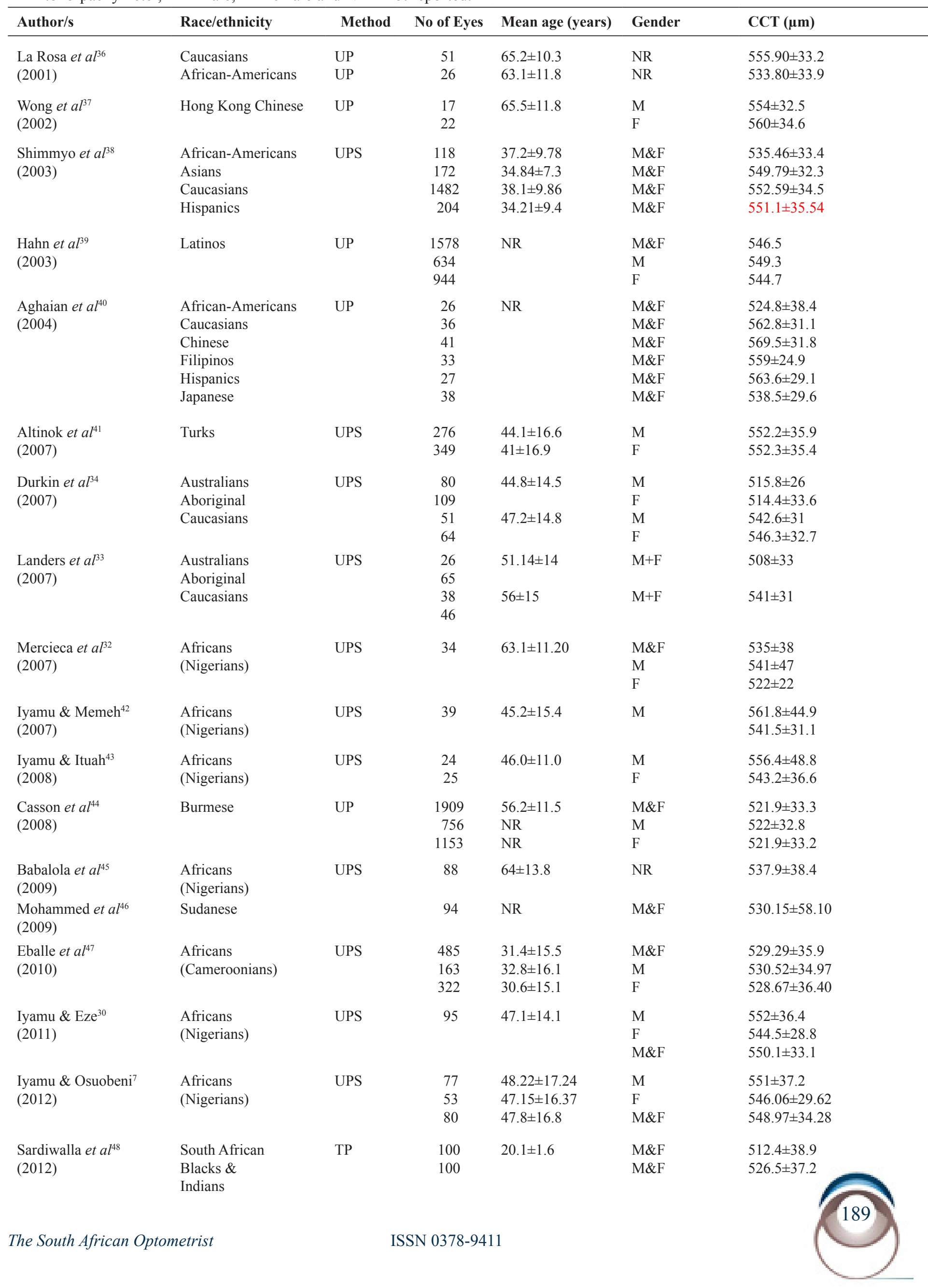




\section{Factors influencing corneal parameters}

Several factors influence the values of the corneal parameters as discussed above. These factors include age, gender, race and ethnicity, axial length and refractive status of the eye as well as certain anthropometric factors.

Age

Iyamu and Osuobeni ${ }^{7}$ found that the vertical corneal diameter of the younger age groups 20-40 years was significantly higher $(p=0.01)$ than for the oldest age group (70-79 years). The authors ${ }^{7}$ suggested that this could be due to the smaller average height of the older group. Similarly, the horizontal corneal diameter was significantly different between age groups $(p=0.03)$. Rufer et $a l^{11}$ found that corneal diameter measured with the Orbscan II decreased slightly with age. The decrease in corneal diameter with age together with age-related narrowing of the anterior chamber might have implications such as increasing glaucoma due to compacting of tissue in the angle or changes in the corneal architecture ${ }^{11}$.

Zadnik et $a l^{49}$ and Mohd-Ali et $a l^{50}$ reported that the corneal curvature becomes steeper with increasing age and Hayashi et $a l^{51}$ suggested that this could be due to some physiological changes that alter the elasticity of the cornea thus causing it to become steeper with age.

Several authors ${ }^{32,39,40}$ have reported a significant reduction of CCT with age. Hahn et $a l^{39}$ suggested that the decrease in density of keratocytes with age is responsible for the reduction of CCT values with age.

\section{Gender}

Iyamu and Osuobeni ${ }^{7}$ found that males had significantly wider horizontal corneal diameters than their female counterparts in 130 healthy Nigerians with a mean age of $47.8 \pm 16.8$ years. The authors ${ }^{7}$ concluded that this finding may be explained by the fact that men are generally taller and have correspondingly larger eyes than women. This is similar to the conclusion drawn by Quant et $a l^{52}$, Goh and $\mathrm{Lam}^{53}$ and Wong et $a l^{54}$ who also found that males had significantly wider horizontal corneal diameters than females.

Mohd-Ali et $a l^{50}$ and Matsuda et $a l^{55}$ reported that females had significantly steeper average corneal curvature than males $(p<0.001)$. Also, several studies $^{56-60}$ have shown the tendency for females to have steeper corneas than males due to their shorter axial length. Goh and $\mathrm{Lam}^{53}$ found that Hong Kong Chinese men aged 19-39 years had flatter corneal curvature than women of a similar age range in the same study. This trend was also observed by Lam et $a l^{56}$ in subjects aged 40 years and older. These differences could be due to various factors such as physiological changes due to menstruation in females and refractive errors such as higher degree of myopia in females resulting in steeper corneas ${ }^{27}$.

Several studies ${ }^{32-34,38-40,61}$ have reported that gender influences CCT values. Shimmyo et $a l^{38}$, Hahn et $a l^{39}$ and Garcia-Medina et $a l^{61}$ reported that males had thicker corneas than females. Hahn et al ${ }^{39}$ found that the difference in CCT between the genders was only $4.6 \mu \mathrm{m}$, which is less than the mean interocular difference in CCT $(7.7 \mu \mathrm{m})$ for their normal subjects. Therefore, they concluded that the difference between men and women CCT was statistically but not clinically significant. Other authors ${ }^{34,40}$ found that gender had no significant effect on CCT.

\section{Race and ethnicity}

Matsuda et $a l^{55}$ measured the HVID among 125 Asian and 81 Caucasian eyes of different ages. The values varied significantly between Caucasians and Asians, with Asians having smaller values. The authors ${ }^{55}$ suggested that these findings may be due to Asians being smaller in overall height in average than Caucasians and concluded that these may assist contact lens practitioners when choosing lens parameters and may guide contact lens manufacturers in setting parameters for lenses targeted to specific ethnic/population groups.

Lam and Loran ${ }^{27}$ reported that the corneal curvature of Chinese subjects was significantly steeper compared to British subjects of the same age, gender and refractive error. The authors ${ }^{27}$ suggested that this could be due to anatomical differences between the two races. In contrast, Shimmyo et al ${ }^{38}$ compared corneal curvature measurements of Caucasians, Hispanics, Asians and African Americans and found no significant differences between the races studied. The difference between these results could have been influenced by the fact that in Shimmyo et $a l^{38}$, the number of subjects in each category varied, with the largest number of subjects being Caucasians. 
Studies $^{38,} 39$ have reported differences in CCT between different racial and ethnic groups. Shimmyo et $a l^{38}$ showed that African Americans and other populations of African descent have thinner CCT than other races. Sardiwalla et al ${ }^{48}$ compared CCT values of 100 Black and 100 Indian students from the University of KwaZulu-Natal, South Africa and found smaller values than those reported in other Black $^{38,47}$ and Asian ${ }^{62,63}$ populations. The authors ${ }^{48}$ suggested that this may result in a delayed diagnosis of glaucoma because of low IOP values expected in these ethnic groups in South Africa.

\section{Axial length}

Eyes with longer axial lengths have been reported to be associated with wider corneal diameters ${ }^{64}$. Lam et $a l^{56}$ and Osuobeni ${ }^{58}$ found a positive correlation between corneal radius of curvature and axial length. Chen et $a l^{65}$ have shown that eyes with longer axial lengths tended to have flatter corneas $(r=-0.502, p<$ 0.001 ) and Chang et $a l^{66}$ reported that longer eyes are associated with thinner CCT.

\section{Refractive status}

Zha et $a l^{21}$ assessed corneal diameters of 231 myopic eyes and 129 emmetropic eyes with the Orbscan II topography system. Eyes were divided into four groups as follows: Group 1: the emmetropic group with spherical equivalents (SE) between -0.50 and $0.50 \mathrm{D}$; Group 2 low myopia with SE between -0.50 and -3 D; Group 3: median myopic group, SE between -3 and -6 D and Group 4: high myopia group with SE $-6 \mathrm{D}$ and higher. The results showed that eyes with myopia of $-3 \mathrm{D}$ and higher had lower corneal diameter values.

Goh and $\mathrm{Lam}^{53}$ and Lam et $a l^{56}$ reported that the average radius of curvature did not vary significantly with the refractive status; however, myopes tended to have steeper corneas, followed by the emmetropes and lastly, the hyperopes. A subsequent study by Osuobeni ${ }^{58}$ found similar results. Scott and Grosvenor ${ }^{67}$ have explained this apparent contradiction by indicating that myopic eyes, which are long, have steeper or shorter radius of curvature because, together with an increase in axial length, corneal steepening also occurs during the development of myopia.

Mohammed et $a l^{46}$ found that CCT correlates with refractive error, and myopes have the thinnest CCT $(449.65 \pm 39.27 \mu \mathrm{m})$, followed by emmetropes $(542.66 \pm 46.35 \mu \mathrm{m})$ and hyperopes $(557.67 \pm 41.83$ $\mu \mathrm{m})$. This is consistent with the findings of Nemesure et $a l^{68}$ who found that CCT was directly related to refractive error. Price et a ${ }^{69}$ suggested that thin CCT associated with myopic eyes may help explain their increased susceptibility to glaucoma.

\section{Anthropometric factors}

Iyamu and Osuobeni ${ }^{7}$ have suggested that smaller corneal diameter may be associated with smaller average height. Eysteinsson et $a l^{70}$ examined the relationship between adult stature, age and ocular dimensions in the largely homogenous white population of Reykjavik in Iceland. It was found that height was positively correlated with the radius of corneal curvature $(95 \%$ CI $0.004-0.011 \mathrm{~m}, p<0.001)$. Nangia et $a l^{71}$ investigated associations between anthropometric parameters and ocular dimensions in a typical rural society untouched by the effects of urbanization in central India and found that after adjusting for age, gender, level of education and body mass index (BMI), taller subjects had larger eyes with flatter corneas. The authors ${ }^{71}$ concluded that since the occurrence of some ocular diseases depends on eye size and refractive error, the results may be helpful for screening examinations and for elucidating pathogenic associations. Galgauskas et $a l^{72}$ evaluated CCT of 518 eyes of a normal Lithuanian population to describe the relationship between CCT and anthropometric factors which included height and weight and the results showed that CCT correlated with height $(r=$ $0.108, p=0.00)$.

\section{Inter-parameter relationships (CCT and corneal curvature)}

Sawada et $a l^{73}$ reported a positive correlation between CCT and corneal curvature in Japanese subjects $(N=3021)$ aged 40 years or older. However, Chen et $a l^{65}$ found no significant correlations $(r=$ $0.013, p=0.770$ ) between the two parameters in 500 normal Taiwanese Chinese adults, aged 40-80 years. Recently, Iyamu and Eze ${ }^{30}$ investigated the relationship between CCT and corneal curvature in 95 Nigerian adults (56 males and 39 females) aged between 20 and 69 years (the mean and standard deviation were 
$47.1 \pm 14.1$ years). No significant association was found between CCT and corneal curvature $(r=0.18$, $p=0.07)$. The authors did not provide an explanation for their findings.

\section{Conclusion}

Corneal parameters such as CD, ACC and CCT provide information about the healthy cornea and possible changes associated with ocular diseases or other factors such as ageing gender, ethnicity, et cetera. Normal values for $\mathrm{CD}$ in adults range from 10.50 to $12.75 \mathrm{~mm}$, the ACC ranges from 7.06 to 8.66 $\mathrm{mm}$ and CCT ranges from 512 to $569.5 \mu \mathrm{m}$. These corneal parameters vary with age, gender, ethnicity, refractive state, stature and anthropometric factors. Such relationships may be important for early and accurate diagnosis of corneal diseases and glaucoma, and may also provide insight into disease mechanisms and processes.

\section{References}

1. Ruskell GL, Bergmanson JPG. Anatomy and physiology of the cornea and related structures. In: Phillip AJ, Speedwell L, eds. Contact Lenses. $5^{\text {th }}$ Ed. Oxford: ButterworthHeinemann, 2006.

2. Dua HS, Faraj LA, Said D, Gray T, Lowe J. Human corneal anatomy redefined: a novel pre-Descement's layer (Dua's Layer). Ophthalmology 2013 May 25. [Epub ahead of print].

3. Wu RY, Zheng YF, Wong YY, Cheung CYC, Loon SC, Chauhan BC, Aung T. Relationship of central corneal thickness with optic disc parameters: The Singapore Malay Eye Study. Inv Ophthalmol Vis Sci 201052 1320-1324.

4. Kanski JJ. Clinical ophthalmology, a systemic approach, $5^{\text {th }}$ Ed. Edinburgh: Butterworth-Heinemann, 2003.

5. Seitz B, Langenbucher A, Zagrada D, Budde W, Kus MM. Corneal dimensions in patients with various types of corneal dystrophies and their impact on penetrating keratoplasty. Klin Monatsbl Angenheilkd 2000217 152-158.

6. Denniston AKO, Murray PI. Oxford handbook of ophthalmology (OUP), 2 ${ }^{\text {nd }}$ Ed. Oxford: Oxford University Press, 2009.

7. Iyamu E, Osuobeni E. Age, gender, corneal diameter, corneal curvature and central corneal thickness in Nigerians with normal intra ocular pressure. J Optom 20125 87-97.

8. Veys J, Meyler J, Davies I. Essential contact lens practice, $1^{\text {st }}$ Ed. Edinburgh: Butterworth-Heinemann, 2002.

9. Ashaye AO, Olowu JA, Adeoti CO. Corneal diameters in infants born in two hospitals in Ibadan, Nigeria. East Afr Med J 200683 631-636.

10. Durukan AH, Mutlu FM, Sahin OF, Altinsoy HI, Bayer A, Celik Y. The importance of corneal diameter in cases developing glaucoma after childhood cataract surgery. Gul Med J 200547 94-96.

11. Rufer F, Schroder A, Erb C. White-to-white corneal diameter: Normal values in healthy humans obtained with the Orbscan II topography system. Cornea 200524 259261.

12. Pinero DP, Plaza Punche AB, Alio JL. Corneal diameter measurements by corneal topography and angle-to-angle measurements by optical coherence tomography: evaluation of equivalence. J Cataract Refract Surg 200834 126-131.

13. Hashemi H, KhabazKhoob M, Yazdani K, Mehravaran S, Mohammad K, Fotouhi A. White-to-white corneal diameter in the Tehran Eye Study. Cornea 2010 29 9-12.

14. Ganguli D, Roy IS, Biswas SK, Sengupta M. Study of corneal power and diameter in simple refractive error. Ind $J$ Ophthalmol 197523 6-11.

15. Baumeister M, Terzi E, Ekici Y, Kohnen T. Comparison of manual and automated methods to determine horizontal corneal diameter. J Ref Surg 200430 374-380.

16. Baumeister M, Terzi E, Ekici Y, Kohnen T. Comparison of manual and automated methods to determine horizontal corneal diameter. J Cataract Refract Surg 200430 374-380.

17. Salouti R, Nowroozzadeh MH, Zamani M, Ghoreyshi M, Salouti R. Comparisons of horizontal corneal diameter measurements using Galilei, EyeSys and Orbscan II systems. Clin Exp Optom 200992 429-433.

18. Kohnen T, Thomala MC, Cichocki M, Strenger A. Internal anterior chamber diameter using optical coherence tomography compared with white-to-white distances using automated measurements. J Cataract Refract Surg 200632 1809-1813.

19. Dinc UA, Oncel B, Gorgun E, Yenerel MN, Alimgil L. Assessment and comparisons of anterior chamber dimensions using various imaging techniques. Ophthal Surg Lasers Imaging 201041 115-122.

20. Sanchis-Gimeno JA, Sanchez-Zuriaga D, Martinez-Soriano F. White-to-white corneal diameter, pupil diameter, central corneal thickness and thinnest corneal thickness values of emmetropic subjects. Surg Radiol Anat 201234 167-170.

21. Zha Yi, Feng Wangqiang, Han Xiaochui, Cai Jianqiu. Evaluation of myopic corneal diameter with the Orbscan II topography system. Graef Arch Clin Exp Ophthalmol 2013 $251537-541$.

22. Bene P, Synek S, Petrová S. Corneal shape and eccentricity in population. Coll Antropol 201337 117-120.

23. Kiely PM, Smith G, Carney LG. Meridional variations of corneal shape. Am J Physiol Opt 198461 619-626.

24. Fledelius HC, Stubgaard M. Changes in refraction and corneal curvature during growth and in adult life. Acta Ophthalmologica Scan 198664 487-491.

25. Guillon M, Lydon DPM, Wilson C. Corneal topography: a clinical model. Ophthal Physiol Opt 19866 47-56.

26. Dunne MCM, Royston JM, Barnes DA. Posterior corneal surface toricity and total corneal astigmatism. Optom Vis Sci 199168 708-710.

27. Lam C, Loran DFC. Video-keratoscopy in contact lens practice. J Br Contact Lens Assoc 199114 109-114. 
28. Lam AKC, Douthwaite WA. Application of a modified keratometer in the study of corneal topography on Chinese subjects. Ophthal Physiol Opt 199616 130-134.

29. Cheung S, Cho P, Douthwaite W. Corneal shape of Hong Kong Chinese. Ophthal Physiol Opt 200020 119-125.

30. Iyamu E, Eze NM. The relationship between central corneal thickness and corneal curvature in adult Nigerians. $S$ Afr Optom 201170 44-50.

31. Doughty M, Jonuscheit S. Pachymetry Part 1: Defining normal corneal thickness and normal IOP measures. Optician 2005230 27-31.

32. Mercieca K, Odogu V, Fiebai B, Arowolo O, Chukwuka F. Comparing central corneal thickness in a sub-Saharan cohort to African Americans and Afro Caribbeans. Cornea 200726 557-560.

33. Landers JA, Billing KJ, Mills RA, Henderson TR, Craig JE. Central corneal thickness of indigenous Australians within central Australia. Am J Ophthalmol 2007143 360-362.

34. Durkin SR, Tan EWH, Casson RJ, Selva D, Newland HS. Central corneal thickness among Aboriginal people attending eye clinics in remote South Australia. Clin Exp Ophthalmol 200735 728-732.

35. Swartz T, Marten L, Wang M. Measuring the cornea: the latest developments in corneal topography. Curr Opin Ophthalmol 200718 325-333.

36. La Rosa FA, Gross RL, Orengo-Nania S. Central corneal thickness of Caucasians and African Americans in glaucomatous and nonglaucomatous populations. Arch Ophthalmol 2001119 23-27.

37. Wong ACM, Wong CC, Yuen NSY, Hui SP. Correlational study of central corneal thickness measurements on Hong Kong Chinese using optical coherence tomography, Orbscan and ultrasound pachymetry. Eye 200216 715-721.

38. Shimmyo M, Ross AJ, Moy A, Mostafavi R. Intraocular pressure, Goldmann applanation tension, corneal thickness, and corneal curvature in Caucasians, Asians, Hispanics, and African Americans. Am J Ophthalmol 2003136 603-613.

39. Hahn S, Azen S, Ying-Lai M, Rohit V, the Los Angeles Latino Eye Study Group. Central corneal thickness in Latinos. Inv Ophthalmol Vis Sci 200344 1508-1512.

40. Aghaian E, Choe JE, Lin S, Stamper RL. Central corneal thickness of Caucasians, Chinese, Hispanics, Filipinos, African Americans, and Japanese in a glaucoma clinic. Ophthalmology 200411 2211-2219.

41. Altinok A, Sen E, Yazici A, Aksakal FN, Oncul H, Koklu GT. Factors influencing central corneal thickness in a Turkish population. Curr Eye Res 200732 413-419.

42. Iyamu E, Memeh M. The association of central corneal thickness with intraocular pressure and refractive error in a Nigerian population. Online J Health Allied Sci 2007 1-7.

43. Iyamu E, Ituah I. The relation between central corneal thickness and intraocular pressure: a comparative study of normal and glaucoma subjects. Afr J Med Sci 200837 345353.

44. Casson RJ, Abraham LM, Newland HS, Muecke J, Sullivan T, Seva D, Aung T. Corneal thickness and intraocular pressure in a nonglaucomatous Burmese population: The Meiktila Eye Study. Arch Ophthalmol 2008126 981-985
45. Babalola OE, Kehinde AV, Iloegbunam AC, Akinbinu T, Moghalu C, Onuoha I. A comparison of the Goldmann applanation and non-contact (Keeler Pulsair Easy Eye) tonometers and the effect of central corneal thickness in indigenous African eyes. Ophthal Physiol Opt 200929 182186.

46. Mohamed NY, Hassan MN, Ali NAM, Binnawi KH. Central corneal thickness in Sudanese population. Sud $J$ Ophthalmol 20091 29-32.

47. Eballe AO, Koki G, Ellong A, Owono D, Epee E, Bella LA, Mvongo CE, Kouam J. Central corneal thickness and intraocular pressure in the Cameroonian nonglaucomatous population. Clin Ophthalmol 20104 717-724.

48. Sardiwalla Z, Moodley D, Ndawonde T, Madikizela A, Ngobese N, Thobela N, Oduntan OA. A comparative study of central corneal thickness (CCT) and intraocular pressure (IOP) in University of KwaZulu-Natal students of Black and Indian ethnicity. S Afr Optom 201271 171-177.

49. Zadnik K, Mutti DO, Mitchell GL, Jones LA, Burr D, Moeschberger ML. Normal eye growth in emmetropic school children. Optom Vis Sci 200481 e.819.

50. Mohd-Ali B, Afzamshah MAS, Mohammed Z, Mohidin M. Ocular dimensions of young Malays in Malaysia. J Sains Kesihatan Malaysia 20119 35-39.

51. Hayashi K, Hayashi H, Hayashi F. Topographic analysis of the changes in corneal shape due to aging. Cornea 199541 527-532.

52. Quant JR, Woo GC. Eye position and head size in Chinese population: a comparison of the Chinese from Hong Kong with the Chinese from Guandong Province. Optom Vis Sci 199269 793-796.

53. Goh WSH, Lam CSY. Changes in refractive trends and optical components of Hong Kong Chinese aged 19 - 39 years. Ophthal Physiol Opt 199414 378-382.

54. Wong TY, Foster PJ, Johnson, GJ, Klein BEK, Seah SKL. The relationship between ocular dimensions and refraction with adult stature: the Tanjong Pagar survey. Inv Ophthalmol Vis Sci 200142 1237-1242.

55. Matsuda LM, Woldorff CL, Kame RT, Hayashida JK. Clinical comparison of corneal diameter and curvature in Asian eyes with those of Caucasian eyes. Optom Vis Sci $19936951-54$.

56. Lam CSY, Goh WSH, Tang YK, Tsui KK, Wong WC, Man TC. Changes in refractive trends and optical components of Hong Kong Chinese aged over 40 years. Ophthal Physiol Opt 199414 383-388.

57. Goss DA, Van Veen HG, Rainey BB, Feng B. Ocular components measured by keratometry, phakometry, and ultrasonography in emmetropic and myopic optometry students. Optom Vis Sci 199774 489-495.

58. Osuobeni EP. Ocular components values and their intercorrelations in Saudi Arabians. Ophthal Physiol Opt 199919 489-497.

59. AlMahmoud T, Priest D, Munger R, Jackson WB. Correlation between refractive error, corneal power, and thickness in a large population with a wide range of ametropia. Inv Ophthalmol Vis Sci 201152 1235-1242.

60. Fanny A, Quattarra A, Aka J, Coulibaly F, Gbe K, Boni 
S, Berete-Coulibaly R, Konan-Toure ML, Adjorlolo C. Ocular biometric values of the black African patient and theoretical consideration of the role of these values in various pathologies: analysis of 325 eyes. J Francais D' Ophtalmolgie 200730 88-72.

61. Garcia-Medina M, Garcia-Medina JJ, Garrido-Fernandez P, Galvan-Espinosa J, Martin-Molina J, Garcia-Matura C, Perez-Pardo S, Pinazo-Duran MD. Central corneal thickness, intraocular pressure and degree of myopia in adult myopic population aged 20 to 40 years in Southeast Spain: determination and relationships. Clin Ophthalmol 20115 249-258.

62. Godar ST, Kaini KR, Khattri JB. Factors affecting the central corneal thickness in Nepalese population. Nepal $J$ Med Sci 20121 7-10.

63. Nangia V, Jonas JB, Sinha A, Matin A, Kulkarni M. Central corneal thickness and its association with ocular and general parameters in Indians: The Central India Eye and Medical Study. Ophthalmology 2010117 705-10.

64. Hosny M, Alio MJ, Claramointe P, Attia WH, PerezSantonja JJ. Relationship between anterior chamber depth, refractive state, corneal diameter, and axial length. $J$ Ref Surg 200016 336-340.

65. Chen MJ, Liu YT, Tsai CC, Chen YC, Chou CK, Lee SM. Relationship between central corneal thickness, refractive error, corneal curvature, anterior chamber depth and axial length. J Chin Med Assoc 200972 133-137.

66. Chang SW, Tsai IL, Hu FR, Lin LL, Shih YF. The cornea in young myopic adults. Br J Ophthalmol 200185 961-970.

67. Hosny M, Alio MJ, Claramointe P, Attia WH, PerezSantonja JJ. Relationship between anterior chamber depth, refractive state, corneal diameter, and axial length. J Refract Surg 200016 336-340.

68. Nemesure B, Wu SY, Hennis A, Leske MC. Corneal thickness and intraocular pressure in the Barbados eye studies. Arch Ophthalmol 2003121 240-244.

69. Price FW, Koller DL, Price MD. Central corneal thickness in patients undergoing laser in situ keratomileusis. Ophthalmology 1999106 2216-2220.

70. Eysteinsson T, Jonasson F, Arnarsson A, Sasaki H, Sasaki K. Relationship between ocular dimensions and adult stature among participants in the Reykjavik Eye Study. Acta Ophthalmologica Scan 200583 734-738.

71. Nangia V, Jonas JB, Matin A, Kulkarni M, Sinha A, Gupta R. Body height and ocular dimensions in the adult population in rural central India. The Central India Eye and Medical Study. Graef Arch Clin Exp Ophthalmol 2010248 1657-1666.

72. Galgauskas S, Garlaite O, Juodkaite G, Tutkuviene J, Asoklis R. The correlation between central corneal thickness, ocular and general parameters. Acta Ophthalmologica 200987 doi: 10.1111/j.1755-3768.2009.202.x.

73. Sawada A, Tomidokoro A, Araie M, Iwase A, Yamato T. Refractive errors in an elderly Japanese population: The infection after LASIK. Ophthalmology 2003110 276-285. 